\title{
The Relationship between Brand Credibility and Customers' Behavioral Intentions. With Reference To Iranian Service Market
}

\author{
Zahra Sayed Ghorban
}

\begin{abstract}
Brand credibility and its benefits still needs to be investigated in different contexts using distinctive industries. Credibility has been argued to enable firms to enhance their relationships with their respective customers and would lead to higher satisfaction and commitment among customers and make them stay with the current brand. By analyzing 147 data from telecommunication service users in Iran using SEM, this study found 1) brand credibility is positively related to satisfaction, loyalty commitment, and continuance commitment; and 2) higher satisfaction and commitment would lead to lower switching propensity among customers.
\end{abstract}

Keywords: Brand credibility, Commitment, Satisfaction, Switching propensity.

\section{Introduction:}

During the recent years, scholarly works in the marketing area of research has been experiencing a tremendous amount of attention toward investigating brand and its ramifications [1-3]. There are evidences offered for the influential role brand can play in boosting marketing activities of the firm, providing wider recognition, and gaining sustainable competitive advantages enabling companies to differentiate their products or services from those of competitors[e.g. 3, 4, 5, 6].

The concept of brand credibility introduced and conceptualized by Erdem and Swait [7] has been attracting attentions from academicians [8-10]. Brand credibility is defined as "Consistently delivering what is promised" [11], in which customers of a given brand (considered as being credible) would perceive the brand to have the necessary willingness and capability to deliver the promises [7].

On the other hand, studying the importance of customer retention on firm performance has been conducted and proposed to be significant [10]. Scholars have shown great amount of interest in studying the elements that would lead on reducing customers' switching propensity. Previous researches have established the relationship of brand reputation to loyalty and satisfaction among customers [12], and there are arguments presented regarding the importance role that brand could play in building a good relationship with customers[10].

In building sustainable relationship with customers, brand credibility has shown to play a key role, in which credibility is believed to enhance customers' perception [10, 12, 13]. Based on the arguments of Erdem and Swait [7], customers are unaware of a given products' characteristics and feature which would bring asymmetric kind of information interacting between the firms and customers. Credibility of a given brand is argued to be able to overcome this asymmetric nature of information in the business environment $[7,11,14]$. By sending a signal of willingness and being capable of delivering what is promised, the brand credibility would play significant part in replacing the asymmetric information, which would place the customers at disadvantages [10], with credible ones [7].

Scholars have argued that brand credibility would enhance the level of satisfaction and commitment among customers in which would reduce their switching propensity[10]. The proposed framework has been studied in the context of western communities and there is still places for extending and validating the model in different context that those that have been studied so far.

Studying brand in marketplaces in a country like Iran has just started its journey [15] and more investigations need to be conducted to provide insights and implications for this concept in this particular country.Therefore, it is the main interest of this study to empirically examine the relationship between brand credibility and customers switching propensity through their level of satisfaction and commitment.The next parts include hypothesis development, methodology, results, and conclusions.

\section{Background and hypothesis development:}

Uncertainty about a particular product or service from the customers' side would be diminished if a given brand is regarded as being credible, which could help customers to distinguish the right information and claims from the wrong ones[7, 11]. Since customers are not as much aware about the products and services provided as the firms, the brand credibility would avoid imperfect information and assist firms to stay away from the asymmetric nature of information about their products and services [7]. Based on the signaling theory [16], when consumers are not certain about the products or the services attributes, this theory suggests that credibility is a key determinant of a particular brand to pass on the information and avoid asymmetric 
understanding. A signal is defined as "an action that the seller can take to convey information credibly about unobservable product quality to the buyer" [17]. Erdem and Swait [7] considered the brand as a signal that can convey the credible information about the products and services, and would enable the firms to overcome the asymmetric nature of the information that might be flowing between customers and firms. As they mentioned "a brand signal is composed of a firm's past and present marketing mix strategies and activities associated with that brand. In other words, a brand becomes a signal because it embodies (or symbolizes) a firm's past and present marketing strategies" (p. 135).

The notion of brand credibility was first conceptualized by Erdem and Swait [7]. "The brand credibility (i.e., the credibility of a brand as a signal) is defined as the believability of the product position information contained in a brand, which entails "consistently delivering what is promised" [11]. Based on their definition, brand credibility has two dimensions: trustworthiness and expertise. Trustworthiness refers to the willingness and expertise refers to the capability of the brand to deliver what it has promised [11,14], failing to do so would gradually wear away the brand equity.

On the other hand, studying the importance of customer retention on firm performance has been gaining attentions and scholars have shown great amount of interest in investigating the elements that would lead to reduction in customers' switching propensity [e.g. 10]. Credibility is believed to enhance customers' perception of the environment relating to retailing [18], while it is an argument proposing that brand could be an affective relational tool in the firms' customer relationship management arsenal [10]. Sweeney and Swait [10] argued that customers value brands since they decrease the associated risks and streamline the decision making process for customers based on the claim that a brand acts as a signal to overcome the asymmetric nature of information exchanging between firms and customers [7].

Brands by attracting new customers and maintaining the existing ones add values to the firms $[10,19]$ and build long relationship with customers [10,20,21]. By sending a signal of willingness and being capable of deliver what is promised, brand credibility would play significant part in replacing the asymmetric information, which would place the customers at advantages [10], with credible ones. This signal when becomes credible would demonstrate that a given brand have the expertise and trustworthy to fulfill its claims [7] and is argued to enhance satisfaction among customers [10].

On the other hand there are evidences of the direct relationship of trust in service providers and satisfaction among customers from service industry [22, 23]. Sweeney and Swait [10] also found that positive relationship between brand credibility and customer satisfaction and, mentioned, "brand credibility is a long-term summary of the customers' interaction with the provider in terms of service brand stability, which in turns explain the long-term summative and more general concept of satisfaction" (p. 184).

In another study, brand experience demonstrated to positively related to satisfaction, trust, and loyalty [24]. In this study, authors argued that a brand is able to build relationships with customers in their point of view. Higher level of satisfaction, therefore, would lead to higher level of brand loyalty and commitment. Sweeney and Swait [10] in providing more insights, discussed that brand credibility conveys that a given brand is trustworthy, which would lead to a sense of loyalty and enables customers to rely on the claims made by the firms $[25,26]$. They also provided empirical evidence for the positive influence of brand credibility on loyalty commitment and continuance commitment among customers when they enhance a given brand as credible.

Based on the above discussions and the framework proposed and examined by Sweeney and Swait [10], the following hypotheses are proposed:

H1: Brand credibility is positively related to satisfaction.

H2: Brand credibility is positively related to loyalty commitment.

H3: Brand credibility is positively related to continuance commitment.

Customer relationship management is believed to be a significant driver of reducing customers' intention to engage in switching behaviors [27, 28]. Sweeney and Swait [10] proposed and examined that loyalty and continuance commitment would lead to lower level of switching propensity among customers. Using the framework proposed by Bagozzi [29], which follows that appraisal (service quality)-emotional response (satisfaction)-coping (behavioral intentions), Sweeney and Swait [10] investigated the relationship of satisfaction, loyalty commitment, and continuance commitment with switching propensity among customers. They found that the negative relationships exit between those variables and switching propensity. Based on the framework proposed by them, the following hypotheses are proposed to be investigated in different context:

H4: Satisfaction is negatively related to switching propensity.

H5: Loyalty commitment is negatively related to switching propensity.

H6: Continuance commitment is negatively related to switching propensity.

\subsection{Sample:}

\section{Methodology:}

The data for this study was collected from the students in different universities in the city of Tehran, the capital city of Iran. The respondents were the usual customers and users of the mobile communication 
services such as SIM cards and broadband services provided by one of the biggest providers known as Iran Cell, which has been operating for several years following its foundation as a private company.There are also a number of competitors offering similar services and products such as the ones provided by the Ministry of Communication itself known as Hamrahe Avval. The total number of 200 questionnaires was distributed amongundergraduate students, who were known to be the users of Iran Cell services, out of which 147 valid responses received (74\% response rate).

\subsection{Back Translation:}

Following what Mullen [30] suggested for the procedure of back translation in order to maximize translation equivalence, an English language professor and Marketing professor in Iran translated the instruments in this study into the language spoken in Iran (Persian). Subsequently, a language expert engaged in translating the instruments back into English language. Another English language professor was requested to compare the two English version of the instrument to find out if there are more than $70 \%$ similarities between the two versions.

\subsection{Instruments:}

Brand credibility was measured by 6-items questionnaire developed by Erdem and Swait [7]. 5-item questionnaire was used to measure satisfaction[10, 31]. Loyalty and continuance commitment measured by items adapted from Meyer and Allen [32, 33]. To measure switching propensity 2 items used from Zeithaml, et al.[34]. All instruments were based on 9-point Scale from 1 designating Strongly Disagree to 9 designating Strongly Agree.

\subsection{Reliability and Validity Analysis:}

Cronbach's Alpha was used to measure the reliability level of the instruments included for this study. All reliabilities were between .94 and .97 establishing that these instruments are reliable to measure the proposed variable, since all were above .60 [35].

Exploratory factor analysis (EFA) was conducted to find out if the items would produce the proposed factor and if they would load on their respective factor in a strong way. Using principal component analysis with oblique rotation technique five distinct factors were suggested and all items loaded strongly on their relevant factor. Applying orthogonal rotation approach resulted in obtaining similar result to those of oblique technique verifying convergent and discriminant validity of the instruments.

Following the above procedure, confirmatory factor analysis (CFA) was conducted using AMOS with maximum likelihood estimation and the results shown in Table 1.

Table 1: Confirmatory Factor Analysis

\begin{tabular}{|c|c|c|c|c|c|c|c|c|c|}
\hline $\begin{array}{l}\text { Variabl } \\
\text { es }\end{array}$ & $\chi^{2}$ & $d f$ & $\begin{array}{c}\chi^{2} / d \\
f\end{array}$ & GFI & NFI & CFI & $\begin{array}{c}\mathrm{RM} \\
\mathrm{R}\end{array}$ & $\begin{array}{c}\text { RMSE } \\
\text { A }\end{array}$ & $\begin{array}{c}\text { Loadin } \\
\text { gs }\end{array}$ \\
\hline $\mathrm{BC}$ & $\begin{array}{c}11.05 \\
9\end{array}$ & 9 & $\begin{array}{l}1.2 \\
29\end{array}$ & .98 & .99 & $\begin{array}{c}1.0 \\
0\end{array}$ & $\begin{array}{c}.05 \\
2\end{array}$ & .040 & All>.86 \\
\hline SAT & 9.693 & 4 & $\begin{array}{l}2.4 \\
23\end{array}$ & .97 & .99 & .99 & $\begin{array}{c}.08 \\
4\end{array}$ & .090 & All>.68 \\
\hline LC & 3.092 & 4 & $\begin{array}{c}.77 \\
3\end{array}$ & .99 & .99 & $\begin{array}{c}1.0 \\
0\end{array}$ & $\begin{array}{c}.02 \\
8\end{array}$ & .000 & All $>.72$ \\
\hline $\mathrm{CC}$ & \multicolumn{8}{|c|}{ Saturated Model } & All $>.95$ \\
\hline SP & \multicolumn{8}{|c|}{ Saturated Model } & All $>.89$ \\
\hline
\end{tabular}

$\mathrm{BC}=$ Brand Credibility; SAT $=$ Satisfaction; $\mathrm{LC}=$ Loyalty Commitment $\mathrm{CC}=$ Continuance

Commitment; $\mathrm{SP}=$ Switching Propensity

\section{Results:}

All the hypotheses were tested using AMOS with maximum Likelihood Estimation. The following table (Table 2) presents the results obtained.

Table 2: Hypotheses Testing

\begin{tabular}{llccc}
\hline Hypotheses & & Standardized coefficient & $\mathrm{t}$-value & Conclusion \\
\hline H1 & Brand Credibility $\rightarrow$ Satisfaction & $.51^{* * *}$ & 5.662 & Supported \\
H2 & Brand Credibility $\rightarrow$ Loyalty Commitment & $.68^{* * *}$ & 7.620 & Supported \\
H3 & Brand Credibility $\rightarrow$ Continuance Commitment & $.42^{* * *}$ & 5.212 & Supported \\
H4 & Satisfaction $\rightarrow$ Switching Propensity & $-.38^{* * *}$ & -4.705 & Supported \\
H5 & Loyalty Commitment $\rightarrow$ Switching Propensity & $-.26^{* * *}$ & -3.361 & Supported \\
H6 & Continuance Commitment $\rightarrow$ Switching Propensity & $-.22^{* *}$ & -3.034 & Supported \\
Model Fit & $\chi^{2} / d f=223.294 / 197=1.133 ;$ GFI= .89; AGFI=.85; NFI= .95; CFI= .99; RMSEA $=.030$ & \\
\hline
\end{tabular}


As shown in Table 2, brand credibility was found to be significantly related to satisfaction, loyalty commitment, and continuance commitment, while the last three variables were found to be negatively related to switching propensity.

\section{Discussions and Conclusions:}

This study set out to address the issue of brand credibility and its importance in customer relationship management in a particular service provider in Iran. As proposed by different researchers that brand credibility would play a significant role in building and maintaining sustainable customer relationship that would lead to better performance by the firms [10], this study contributed to this issue by empirically examining the proposed relationships. Consistent with the findings from previous research, the present study confirms the positive relationship of brand credibility with satisfaction, loyalty commitment, and continuance commitment. On the other hand, these three variables found to be negatively related to switching propensity.

Findings from this study indicate that when customers perceive a particular brand to be credible, meaning that it would consistently deliver what it promises, they would become satisfied and committed. Customers' level of satisfaction with a given brand would hinge on the level of credibility perceived from that brand in which the level of satisfaction would increase if the level of perception regarding the brand credibility increased. A higher credible brand would be able to make its customers to be committed to it. When it delivers its promises and becomes trustworthy, it would bring loyalty among its customers and they remain to be the users of that particular brand.

Another finding from this study indicates that when customers become satisfied and committed to a given brand, their level of intention to switch to another brand would be significantly diminished. This is another indication of firm-customer relationship in which the perception of a brand to be credible would lead to higher level of satisfaction and commitment, which would consequently lead to lower level of switching propensity. The proposed relationships in this study were examined in different context than those that have studied so far on the brand-CRM-behavioral intention. This study confirms the previous findings in this matter [10] by providing empirical results from a non-western country and from a service point of view.

From the managerial point of view, the findings from this study provide indication for the firms that brands being perceived as credible would intend to have satisfied and committed customers, which would lead to lower intention to switch to another brands. The previous research provided insights for this fact by mentioning, " $\ldots$ understanding that the brand plays a significant role in retaining and expanding a customer franchise should lead management to strongly concentrate on avoiding actions that diminish an any ways the brand's credibility" [10]. Managers should be alert not to promising things that they might not be able to deliver, which would lead to damage the brand credibility and discourage customers by diminishing their level of satisfaction and commitment in the long term.

This study could only focus on one kind of service provider in Iran. Future studies should examine the proposed relationships in different service contexts and expand them even to markets markets in countries like Iran. The concept of brand credibility should be more investigated to see if it could benefit the firms in their financial performances.

\section{Reference:}

[1.] Aaker, D.A., Managing Brand Equity1991, New York, NY: Free Press.

[2.] Aaker, D.A., Leveraging the Corporate Brand. California Management Review, 2004. 46(3): p. 1-6.

[3.] Keller, K.L., Conceptualizing measuring and managing customer-based brand equity. The Journal of Marketing, 1993. 57(1): p. 122

[4.] Buil, I., L. de Chernatony, and E. Martinez, Examining the role of advertising and sales promotions in brand equity creation. Journal of Business Research, 2011(0).

[5.] Doyle, P., Building successful brands: the strategic options. Journal of Marketing Management, 1989. 5(1): p. 77-95.

[6.] Keller, K.L. and D.R. Lehmann, Brands and branding: research findings and future priorities. Marketing Science, 2006. 25(6): p. 740-59.

[7.] Erdem, T. and J. Swait, Brand Equity as a Signaling Phenomenon. Journal of Consumer Psychology, 1998. 7(2): p. 131-157.

[8.] Baek, T.H., J. Kim, and J.H. Yu, The differential roles of brand credibility and brand prestige in consumer brand choice. Psychology and Marketing, 2010. 27(7): p. 662-678.

[9.] Baek, T.H. and K.W. King, Exploring the consequences of brand credibility in services. Journal of Services Marketing, 2011. 25(4): p. $260-272$.

[10.] Sweeney, J. and J. Swait, The effects of brand credibility on customer loyalty. Journal of Retailing and Consumer Services, 2008. 15(3): p. 179-193.

[11.] Erdem, T., J. Swait, and J. Louviere, The impact of brand credibility on consumer price sensitivity. International Journal of Research in Marketing, 2002. 19(1): p. 1-19.

[12.] Selnes, F., An examination of the effect of product performance on brand reputation, satisfaction and loyalty. European Journal of Marketing, 1993. 27(9): p. 19-35.

[13.] Yang, Z., R.T. Peterson, and S. Cai, Services quality dimensions of internet retailing: an exploratory analysis. . Journal of Services marketing, 2003. 17(7): p. 685-700.

[14.] Erdem, T. and J. Swait, Brand Credibility and its Role in Brand Choice and Consideration. Journal of Consumer Research, 2004. 31(1): p. 191-199. 
[15.] Seyed Ghorban, Z., Advertising and brand equity creation. Examination of product market in Iran. International Journal of Business and Management Innovation, 2012. 2(7): p. XXX.

[16.] Spence, M., Market Signaling: Informational Transfer in Hiring and Related Screening Processes 1974, Cambridge, MA: Harvard University Press.

[17.] Rao, A.R., L. Qu, and R.W. Ruekert, Signaling unobservable product quality through a brand ally. Journal of Marketing Researc, 1999. 36(2): p. 258-68.

[18.] Bobinski, J., G. S.,, D. Cox, and A. Cox, Retail "Sale" Advertising, perceived retailer credibility, and price rationale. Journal of Retailing, 1996. 72(3): p. 291-3-6.

[19.] Rust, R.T., V.A. Zeithaml, and K.N. Lemon, Driving Customer Equity: How Customer Lifetime Value is Reshaping Corporate Strategy2000, New York: The Free Press.

[20.] Dall'Olmo Riley, F. and L. de Chernatony, The service brand as relationships builder. British Journal of Management 2000. 11(2): p. $137-150$.

[21.] Davis, R., M. Buchanan-Oliver, and R.J. Brodie, Retail service branding in electronic-commerce environments. Journal of Service Research, 2000. 3(3): p. 178-186.

[22.] Gwinner, K.P., D.D. Gremler, and M.J. Bitner, Relational benefits in service industries: The customer's perspective. Journal of the Academy of Marketing Science, 1998. 26(2): p. 101-114.

[23.] Harris, L.C. and M.M.H. Goode, The four levels of loyalty and the pivotal role of trust: a study of online service dynamics. Journal of Retailing, 2004. 80(139-158).

[24.] Sahin, A., C. Zehir, and H. Kitapçı, The Effects of Brand Experiences, Trust and Satisfaction on Building Brand Loyalty; An Empirical Research On Global Brands. Procedia - Social and Behavioral Sciences, 2011. 24(0): p. 1288-1301.

[25.] Gilliland, D. and D. Bello, Two sides to attitudinal commitment: The effect of calculative and loyalty commitment on enforcement mechanisms in distribution channels. Journal of the Academy of Marketing Science, 2002. 30(1): p. 24-43.

[26.] Wetzels, M., K. de Ruyter, and M. van Birgelen, Marketing service relationships: the role of commitment. Journal of Business and Industrial Marketing, 1998. 13(4/5): p. 406-423.

[27.] Bansal, H.P., P.G. Irving, and S. Taylor, A three-component model of customer commitment to service providers. Journal of the Academy of Marketing Science, 2004. 32(3): p. 234-250.

[28.] Morgan, R.M. and S.D. Hunt, The commitment-trust theory of relationship marketing. Journal of Marketing, 1994. 58(July): p. 20 38.

[29.] Bagozzi, R., The self regulation of attitudes, intentions and behavior. Social Psychology Quarterly, 1992. 55: p. 178-204.

[30.] Mullen, M.R., Diagnosing measurement equivalence in cross-national research. Journal of International Business Studies, 1995. 26(3): p. 573-596.

[31.] Oliver, R.L., Satisfaction: A behavioral perspective on the consumer 1997, New York: McGraw Hill.

[32.] Meyer, J.P. and N.J. Allen, Testing the 'side-bet' theory of organiza- tional commitment: some methodological considerations. Journal of Applied Psychology, 1984. 69(3): p. 372-378.

[33.] Meyer, J.P. and N.J. Allen, Commitment in the Workplace: Theory, Research and Application1997, Thousand Oaks: Sage Publications.

[34.] Zeithaml, V.A., L.L. Berry, and A. Parasuraman, The behavioral consequences of service quality. Journal of Marketing, 1996. 60(2): p. 31-46.

[35.] Nunnally, J.C., Psychometric theory. McGraw-Hill, New York, 1978: p. 23-45. 